\title{
A high fat diet increases mitochondrial fatty acid oxidation and uncoupling to decrease efficiency in rat heart
}

\author{
Mark A. Cole • Andrew J. Murray $\cdot$ Lowri E. Cochlin $\cdot$ Lisa C. Heather • \\ Sara McAleese • Nicholas S. Knight • Elizabeth Sutton • Amira Abd Jamil • \\ Nadege Parassol $\cdot$ Kieran Clarke
}

Received: 14 September 2010/Revised: 12 November 2010/Accepted: 23 December 2010/Published online: 12 February 2011

(C) The Author(s) 2011. This article is published with open access at Springerlink.com

\begin{abstract}
Elevated levels of cardiac mitochondrial uncoupling protein 3 (UCP3) and decreased cardiac efficiency (hydraulic power/oxygen consumption) with abnormal cardiac function occur in obese, diabetic mice. To determine whether cardiac mitochondrial uncoupling occurs in non-genetic obesity, we fed rats a high fat diet $(55 \% \mathrm{kcal}$ from fat) or standard laboratory chow $(7 \% \mathrm{kcal}$ from fat) for 3 weeks, after which we measured cardiac function in vivo using cine MRI, efficiency in isolated working hearts and respiration rates and $\mathrm{ADP} / \mathrm{O}$ ratios in isolated interfibrillar mitochondria; also, measured were medium chain acyl-CoA dehydrogenase (MCAD) and citrate synthase activities plus uncoupling protein 3 (UCP3), mitochondrial thioesterase 1 (MTE-1), adenine nucleotide translocase (ANT) and ATP synthase protein levels. We found that in vivo cardiac function was the same for all rats, yet oxygen consumption was 19\% higher in high fatfed rat hearts, therefore, efficiency was $21 \%$ lower than in controls. We found that mitochondrial fatty acid oxidation rates were $25 \%$ higher, and MCAD activity was $23 \%$ higher, in hearts from rats fed the high fat diet when compared with controls. Mitochondria from high fat-fed rat
\end{abstract}

Mark A. Cole and Andrew J. Murray contributed equally to this work.

M. A. Cole $(\varangle) \cdot$ A. J. Murray · L. E. Cochlin .

L. C. Heather - S. McAleese - N. S. Knight · E. Sutton ·

A. A. Jamil · N. Parassol - K. Clarke

Department of Physiology, Anatomy and Genetics,

University of Oxford, Parks Rd, Oxford OX1 3PT, UK

e-mail: mark.cole@dpag.ox.ac.uk

Present Address:

A. J. Murray

Department of Physiology, Development and Neuroscience,

University of Cambridge, Downing Street,

Cambridge CB2 3EG, UK hearts had lower ADP/O ratios than controls, indicating increased respiratory uncoupling, which was ameliorated by GDP, a UCP3 inhibitor. Mitochondrial UCP3 and MTE1 levels were both increased by $20 \%$ in high fat-fed rat hearts when compared with controls, with no significant change in ATP synthase or ANT levels, or citrate synthase activity. We conclude that increased cardiac oxygen utilisation, and thereby decreased cardiac efficiency, occurs in non-genetic obesity, which is associated with increased mitochondrial uncoupling due to elevated UCP3 and MTE-1 levels.

Keywords Cardiac efficiency - Oxygen consumption . Free fatty acids $\cdot$ Uncoupling $\cdot$ High fat diet $\cdot$ Mitochondria

$\begin{array}{ll}\text { Abbreviations } \\ \text { UCP } & \text { Uncoupling protein } \\ \text { FFA } & \text { Free-fatty acids } \\ \text { PPAR } & \text { Peroxisome proliferator activated receptor } \\ \text { MRI } & \text { Magnetic resonance imaging } \\ \text { MTE-1 } & \text { Mitochondrial thioesterase-1 } \\ \text { ANT } & \text { Adenine nucleotide translocase } \\ \text { MCAD } & \text { Medium chain acyl-CoA dehydrogenase } \\ \text { ACR } & \text { Acceptor control ratio } \\ \text { gww } & \text { Gram wet weight } \\ \text { BSA } & \text { Bovine serum albumin }\end{array}$

Introduction

The metabolic syndrome, defined as central obesity accompanied by any two of hypertriglyceridaemia, decreased HDL cholesterol, hyperglycaemia and hypertension [1], is 
increasingly common in Western populations and is associated with increased risk of type 2 diabetes and cardiovascular disease [15]. Humans with type 2 diabetes have impaired cardiac high energy phosphate metabolism, which precedes changes in contractile function [39] and may arise from abnormal mitochondrial respiration impairing ATP synthesis. Isolated, perfused hearts from mice with type 2 diabetes have decreased efficiency when compared with wild-type mouse hearts [4,23], possibly caused by increased mitochondrial uncoupling protein 3 (UCP3) levels [4]. UCPs allow protons to re-enter the mitochondrial matrix independent of ATP synthase (Fig. 1), a process inhibited by nucleoside di- and triphosphates, including GDP [53]. Cardiac UCP3 mRNA [50] and protein [29] levels increase with high plasma free-fatty acid (FFA) concentrations, acting via peroxisome proliferator-activated receptor $\alpha(\operatorname{PPAR} \alpha)$ [31]. Levels of UCP3 in human heart have been found to correlate positively with plasma FFA concentrations [29] and lowering plasma FFAs decreased UCP3 levels and normalised efficiency in the diabetic mouse heart [23]. High plasma FFAs also increase mitochondrial uncoupling, because fatty acids are intrinsic UCP activators [36]. Activation of PPAR $\alpha$,

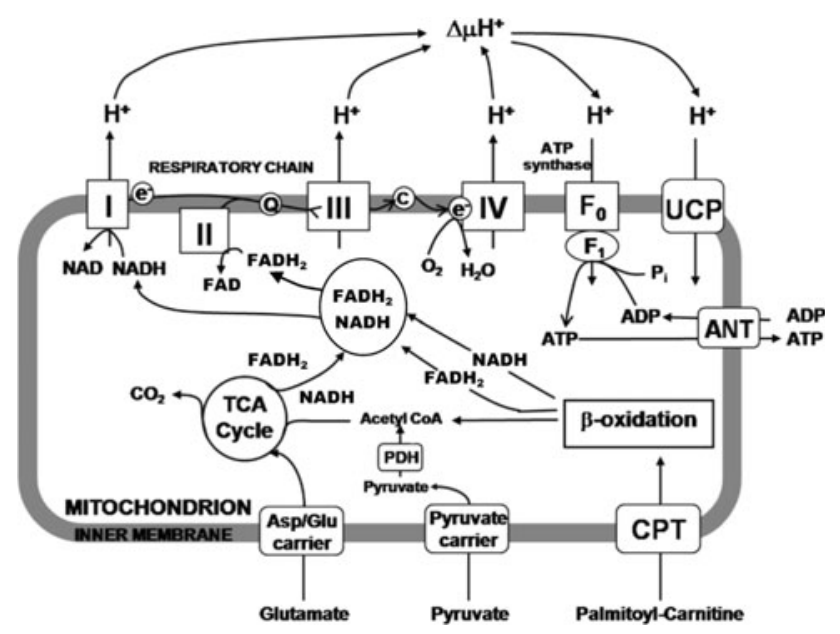

Fig. 1 The metabolic fates of mitochondrial energy substrates. 1 Glutamate enters the mitochondrion via the aspartate/glutamate carrier and is oxidised to $\alpha$-ketoglutarate by glutamate dehydrogenase. 2 Palmitoyl carnitine is imported by the carnitine palmitoyl transferase (CPT) shuttle, and oxidised by $\beta$-oxidation, to reduce $\mathrm{FAD}^{+}$and $\mathrm{NAD}^{+}$to $\mathrm{FADH}_{2}$ and $\mathrm{NADH}$, respectively, producing acetyl CoA. 3 Pyruvate enters via the pyruvate carrier and is oxidised by pyruvate dehydrogenase $(\mathrm{PDH})$ reducing $\mathrm{NAD}^{+}$and producing acetyl CoA. Acetyl CoA enters the tricarboxylic acid (TCA) cycle, producing $\mathrm{NADH}$ and $\mathrm{FADH}_{2}$, which are oxidised by complexes I and II, respectively, of the electron transport chain, which consists of complexes I-IV. Electrons are transferred through the chain to the final acceptor, $\mathrm{O}_{2}$. The free energy from electron transfer is used to pump $\mathrm{H}^{+}$out and generate an electrochemical gradient, $\Delta \mu \mathrm{H}^{+}$, across the inner mitochondrial membrane, which is the driving force for ATP synthesis via ATP synthase. Alternatively, $\mathrm{H}^{+}$can re-enter the mitochondria independent of ATP synthesis, via the uncoupling proteins (UCPs), resulting in the dissipation of energy via increased plasma FFAs, can also upregulate mitochondrial thioesterase-1 (MTE-1), which is believed to work in conjunction with UCP3 to increase mitochondrial uncoupling and/or fatty acid oxidation [45]. Therefore, high plasma FFAs are associated with increased mitochondrial UCP3 levels and uncoupling.

Studies that associate high cardiac UCP levels with elevated circulating FFA concentrations [4, 23, 29] have used the obese $o b / o b$ and diabetic $d b / d b$ mouse models, which have mutations in the leptin and leptin receptor genes, respectively $[27,35]$. It is unknown whether cardiac UCP3 levels and mitochondrial uncoupling are elevated in milder, pre-diabetic forms of obesity, and thereby form an early stage of disease progression. Consequently, we fed rats a high fat diet $(55 \% \mathrm{kcal}$ from saturated fat) or normal laboratory chow (7\% kcal from saturated fat) to induce obesity, but not overt insulin resistance. We measured cardiac function in vivo using magnetic resonance imaging (MRI) and function and efficiency (hydraulic power $/ \mathrm{O}_{2}$ consumption) in isolated, perfused working hearts from these rats. We then isolated cardiac interfibrillar mitochondria and measured mitochondrial respiration rates and ADP/O ratios with glutamate, palmitoyl-carnitine or pyruvate as substrates (Fig. 1). We also measured mitochondrial UCP3, MTE-1, adenine nucleotide translocase (ANT) and $\mathrm{F}_{0} \mathrm{~F}_{1}$ ATP synthase protein levels, as well as activities of the mitochondrial oxidation enzymes, medium chain acyl-CoA dehydrogenase (MCAD) and citrate synthase. We hypothesised that diet-induced high plasma FFA concentrations would increase cardiac mitochondrial UCP3 protein levels, thereby increasing mitochondrial uncoupling and reducing cardiac efficiency.

\section{Materials and methods}

Animals

Male Wistar rats $(\sim 300 \mathrm{~g})(n=36)$ were obtained from a commercial breeder (Harlan, Oxfordshire, UK) and housed in groups of three under controlled conditions for temperature, humidity and light, in accordance with the UK Home Office and US NIH guidelines, with water available ad libitum. All rats were initially fed standard laboratory chow ad libitum (Rat and Mouse No. 1 Maintenance, Special Diet Services, Witham, Essex, UK), which had an Atwater Fuel Energy (AFE) of $3.3 \mathrm{kcal} / \mathrm{g}$, comprising $7.5 \%$ from oil, $17.5 \%$ from protein and $75 \%$ from carbohydrate. Three days after arriving, half the rats were switched from standard chow to a custom-produced high fat diet (Special Diet Services, Witham, Essex, UK), which had an AFE of $5.1 \mathrm{kcal} / \mathrm{g}$, comprising $55 \%$ from oil, $29 \%$ from protein and $16 \%$ from carbohydrate. The remaining rats continued on 
chow. Rats were fed these diets for up to 3 weeks ad libitum, with food intake and body weights measured each day. A 3-week duration of high fat feeding was chosen as that sufficient to significantly elevate plasma FFA as compared to control animals.

\section{Cardiac magnetic resonance imaging}

After 3 weeks of feeding, anaesthesia was induced in one group of control $(n=5)$ and high fat-fed $(n=5)$ rats using $4 \%$ isoflurane in $100 \%$ oxygen. Rats were placed in a purpose built cradle for subsequent vertical positioning in the magnet bore [48]. Maintenance anaesthesia was $1.5-2 \%$ isoflurane at $11 \mathrm{~min}^{-1}$ oxygen flow. Heart electrical activity and respiration were monitored, using an inhouse electrocardiography and respiratory gating device, via subcutaneous needle electrodes inserted into the fore limbs, and a motion loop on the abdomen, respectively.

As described previously [48], magnetic resonance imaging was carried out on an $11.7 \mathrm{~T}(500 \mathrm{MHz})$ vertical bore (123-mm internal diameter) system (Magnex Scientific, Oxon, UK), using a Bruker Avance console (Bruker Medical, Ettlingen, Germany) with a linear transmit and receive, $500 \mathrm{MHz}$ birdcage coil with an inner diameter of $60 \mathrm{~mm}$ (constructed in-house).

Long- and short-axis scout images of the heart, using a cardiac- and respiration-gated segmented fast low angle shot sequence, were used to position 7-8 contiguous, shortaxis slices (slice thickness $1.5 \mathrm{~mm}$ ) covering the entire heart. The sequence was electrocardiogram and respiration gated and between 20 and 30 frames per heart cycle were acquired, depending on the heart rate. The field of view was $5.12 \times 5.12 \mathrm{~cm}$ with a matrix size of $256, \mathrm{TE} /$ $\mathrm{TR}=1.43 / 4.6 \mathrm{~ms}$. One phase-encoding step was acquired per heart beat and four or eight phase encoded steps acquired per respiration cycle, resulting in a total experimental time of approximately $1 \mathrm{~h}$.

Image reconstruction was performed using purposewritten software in Matlab (Mathworks, Natick, Maryland, USA). Raw data were isotropically zero-filled by a factor of two and filtered (modified third-order Butterworth filter) before Fourier transformation, resulting in an in-plane voxel size of $100 \times 100 \mu \mathrm{M}$. Image data were exported into Scion Image (Scion Corporation, Frederick, Maryland, USA). End-diastolic and end-systolic frames were selected according to maximal and minimal ventricular volumes. In both frames, the epicardial border and left ventricular cavity were outlined and left ventricular mass was obtained by multiplying the volume by the specific gravity of myocardial tissue $\left(1.05 \mathrm{~g} / \mathrm{cm}^{3}\right)$. Based on the end-systolic volumes (ESV) and end-diastolic volumes (EDV), all parameters characterising cardiac function, such as stroke volume $(\mathrm{SV}=\mathrm{EDV}-\mathrm{ESV})$, ejection fraction $(\mathrm{EF}=\mathrm{SV} / \mathrm{EDV})$ and cardiac output $(\mathrm{CO}=\mathrm{SV} \times$ heart rate $)$ were calculated.

Isolated working heart perfusion

Another group of control $(n=7)$ and high fat-fed $(n=7)$ rats were anaesthetised with a $0.8 \mathrm{ml}$ i.p. injection of $60 \mathrm{mg} \mathrm{ml}^{-1}$ sodium pentobarbitone (Sagatal, Rhône Mèrieux, Dublin, Ireland). Following the cessation of peripheral nervous function, hearts were excised and arrested using ice-cold modified Krebs-Henseleit buffer $(118 \mathrm{mM}$ $\mathrm{NaCl}, 4.7 \mathrm{mM} \mathrm{KCl}, 1.2 \mathrm{mM} \mathrm{MgSO}, 1.75 \mathrm{mM} \mathrm{CaCl}_{2}$, $0.5 \mathrm{mM} \quad \mathrm{Na}_{2}$ EDTA, $\left.25 \mathrm{mM} \quad \mathrm{NaHCO}_{3}, 1.2 \quad \mathrm{KH}_{2} \mathrm{PO}_{4}\right)$. Hearts were weighed before perfusion, and then perfused in Langendorff mode for $10 \mathrm{~min}$ with modified KrebsHenseleit buffer containing $11 \mathrm{mM}$ glucose, $0.2 \mathrm{mM}$ pyruvate and $0.5 \mathrm{mM}$ lactate as substrates. After left atrial cannulation, hearts were switched to the working mode for $20 \mathrm{~min}$ with $200 \mathrm{ml}$ of recirculating buffer. Preload was $15 \mathrm{mmHg}$ and afterload was $80 \mathrm{mmHg}$. Hearts were then perfused with buffer containing $0.2 \mathrm{mM}$ palmitate prebound to essentially fatty acid free $1.5 \% \mathrm{wt} / \mathrm{vol}$ bovine serum albumin (BSA) for $20 \mathrm{~min}$. This was followed by 20 min perfusion with buffer containing $1 \mathrm{mM}$ palmitate pre-bound to $1.5 \% \mathrm{BSA}$. In four experiments, hearts were perfused with buffer containing $1 \mathrm{mM}$ palmitate, then $0.2 \mathrm{mM}$ palmitate to ensure that the order of buffer change did not affect the results. Aortic and coronary flows were measured every $10 \mathrm{~min}$ and, using online measurement of aortic developed pressure, cardiac power was calculated [3]. Atrial venous oxygen concentration differences were determined using online chemifluorescence methods, which simultaneously monitored temperature-compensated oxygen partial pressure in the atrial inflow line, and from the pulmonary trunk. The oxygen content of buffer flowing in the left atrium was maintained above $550 \mathrm{mmHg}$ throughout all experiments. Heart temperature was maintained at $37.4 \pm 0.2^{\circ} \mathrm{C}$. Myocardial oxygen consumption was calculated using the arterio-venous differences and coronary flows. Cardiac efficiency was calculated from cardiac power and myocardial oxygen consumption [3]. Hearts were snap-frozen in liquid nitrogen for subsequent biochemical analyses.

\section{Isolation of mitochondria}

A further group of control $(n=6)$ and high fat-fed $(n=6)$ rats were anaesthetised as described in the perfusion study. After the cessation of peripheral nervous function, hearts were quickly excised and arrested in ice-cold mitochondrial isolation solution $(100 \mathrm{mM} \mathrm{KCl}, 50 \mathrm{mM}$ MOPS, $1 \mathrm{mM}$ EGTA, $5 \mathrm{mM} \mathrm{MgSO} 4.7 \mathrm{H}_{2} \mathrm{O}, 1 \mathrm{mM}$ ATP, pH 7.4). A sample of whole left ventricle $(\sim 80 \mathrm{mg})$ was washed in 
mitochondrial isolation solution, frozen using pre-cooled Wollenberger clamps under liquid nitrogen and stored at $-80^{\circ} \mathrm{C}$ for later analysis of enzyme activity. The remaining left ventricular tissue was used for mitochondrial isolation. Epididymal fat pads were removed from the carcass and weighed, as an indicator of whole body adiposity [52].

Interfibrillar mitochondria were isolated from rat hearts as previously described [33] except that a modified Chappell-Perry buffer (containing $100 \mathrm{mM} \mathrm{KCl,} 50 \mathrm{mM}$ MOPS, $1 \mathrm{mM}$ EGTA, $5 \mathrm{mM} \mathrm{MgSO}_{4} \cdot 7 \mathrm{H}_{2} \mathrm{O}$, and $1 \mathrm{mM}$ ATP, pH 7.4 at $4^{\circ} \mathrm{C}$ ) was used. The final mitochondrial suspension was immediately used for measurement of mitochondrial respiratory parameters, and the remaining preparation later stored at $-80^{\circ} \mathrm{C}$ for production of protein lysates for immunoblotting.

Measurement of mitochondrial respiratory parameters

Respiratory rates of rat heart mitochondria were measured using a Clark-type oxygen electrode (Strathkelvin Instruments Ltd, Glasgow, UK). Respiration rates were recorded and quantified using 782 Oxygen System v3.0 software (Strathkelvin Instruments). Oxygen concentrations were measured in $0.5 \mathrm{ml}$ respiration medium $(100 \mathrm{mM} \mathrm{KCl}$, $50 \mathrm{mM}$ MOPS, $1.0 \mathrm{mM} \mathrm{KH}_{2} \mathrm{PO}_{4}, 1.0 \mathrm{mg} / \mathrm{ml}$ defatted $\mathrm{BSA}, \mathrm{pH}$ 7.4) in two respiration chambers maintained at $30^{\circ} \mathrm{C}$ containing magnetic stirrers [25]. The chambers were treated identically throughout the experiment, except that one contained $1 \mu \mathrm{mol}$ GDP (dissolved in $10 \mu \mathrm{l}$ of $\mathrm{H}_{2} \mathrm{O}, \mathrm{pH}$ 7.4), added to the respiratory medium at the start of the experiment (i.e. before mitochondria were added) and allowed to mix. GDP is an inhibitor of the mitochondrial uncoupling proteins [53], such that differences between the two chambers indicate the influence of UCP3 on oxygen utilisation. Oxygen concentrations were first recorded in the absence of mitochondria, and after the addition of approximately $0.5 \mathrm{mg}$ mitochondrial protein, assayed using a protein assay kit (Pierce, Rockford IL, USA). Glutamate $(20 \mathrm{mM})$, malate $(5 \mathrm{mM})$ plus pyruvate $(0.5 \mathrm{mM})$ or malate $(5 \mathrm{mM})$ plus palmitoyl carnitine $(0.04 \mathrm{mM})$, were added as substrates, before State III respiration was stimulated by the addition of $100 \mathrm{nmol}$ of ADP. State IV respiration, which occurred when all the ADP added to the respiration medium had been phosphorylated, was subsequently measured. State III and state IV measurements were repeated after addition of a further $100 \mathrm{nmol}$ of ADP. Acceptor control ratios (ACRs) were calculated as an indication of mitochondrial integrity by dividing state III respiration rates by state IV respiration rates. $\mathrm{ADP} / \mathrm{O}$ ratios (the ratios of molecules of ADP phosphorylated for each oxygen atom consumed) were calculated as described by Estabrook [16]. ADP/O ratios are independent of the rates of oxygen consumption and give a more sensitive and precise measure of mitochondrial respiratory coupling than can be inferred from respiration rates alone.

Enzyme analysis

Whole snap-frozen heart tissue was crushed under liquid nitrogen and activities of the mitochondrial $\beta$-oxidation enzyme MCAD and citrate synthase, a measure of mitochondrial content, were measured using methods described previously [20].

Immunoblotting

Levels of cardiac UCP3 protein were measured in mitochondrial preparations by immunoblotting, as described previously [30], using a polyclonal rabbit anti-UCP3 antibody (Alpha Diagnostic International, San Antonio, TX) at a concentration of $1: 1,000$ in $5 \%$ milk TBSTween. MTE-1 protein levels were measured in mitochondrial preparations as described previously [26], using a polyclonal rabbit anti-MTE-1 antibody (gift of Dr Stefan Alexson, Karolinska Institutet, Stockholm, Sweden) at a concentration of 1:2,000 in 5\% milk TBS-Tween. Levels of ANT protein were determined using a polyclonal goat anti-ANT antibody (Santa Cruz Biotechnology, CA, USA) as described previously [29]. Levels of $\mathrm{F}_{0} \mathrm{~F}_{1}$ ATP synthase $\alpha$-subunit protein were determined using a polyclonal mouse anti- $\alpha$ subunit $\mathrm{F}_{0} \mathrm{~F}_{1}$ ATP synthase antibody (Mitosciences Inc, Eugene, USA) at a concentration of 1:2,000 in 5\% milk TBS-Tween. Total cellular GLUT 4 protein content was determined using a monoclonal anti-COOHterminal GLUT4 antibody (kind gift, G.D. Holman, Bath), as described previously [34]. The secondary antibody used, in all cases, was the appropriate horseradish peroxidase conjugate polyclonal antibody (Autogen Bioclear, Wiltshire, UK) at a concentration of $1: 3,500$ in $5 \%$ milk TBS-Tween. Even protein loading and transfer were confirmed by Ponceau staining, and protein levels were related to internal standards to ensure homogeneity between samples and gels. Bands were quantified using UN-SCAN-IT gel software (Silk Scientific, USA), and all samples were run in duplicate on separate gels to confirm results.

To measure oxidative modification of mitochondrial proteins, protein carbonylation was measured using an OxyBlot kit (Millipore, MA, USA). In brief, carbonyl groups were derivatised to 2,4-dinitrophenylhydrazone (DNP) by 2,4-dinitrophenylhydrazine, and proteins were then separated on a gel, using western blotting techniques described above. Blots were incubated with a DNP-specific antibody contained in the kit, and the sum of the separated protein bands was quantified as total protein carbonylation in the sample. 
Blood plasma analyses

At the point of heart excision, blood was taken from the chest cavity, rapidly centrifuged at $1,000 \times g$ at $4{ }^{\circ} \mathrm{C}$, and the plasma frozen at $-80^{\circ} \mathrm{C}$ for biochemical analysis. Lipoprotein lipase inhibitor (2\%) was added to an aliquot of plasma for non-esterified FFA analysis. Plasma levels of glucose, triglycerides, total cholesterol, HDL cholesterol and LDL cholesterol were measured using an ABX Pentra Clinical Chemistry bench-top analyser (Horiba ABX, Montpellier, France). Plasma levels of FFAs were measured using an NEFA assay kit (Wako Chemicals $\mathrm{GmbH}$, Neuss, Germany).

\section{Statistics}

Grouped data (mean \pm SEM) were analysed using twoway ANOVAs. Data involving time or a change in perfusion substrate were analysed using a mixed design ANOVA with repeated measures, using Bonferroni's correction where appropriate. Correlations were tested for significance using Pearson's product moment statistics. The results were considered significantly different at $p<0.05$.

\section{Results}

Morphological parameters and in vivo cardiac function

All rats consumed a similar weight of food each day (Table 1); however, the high fat diet had a greater caloric density than the standard laboratory chow, so the high fat-fed rats consumed $86 \%$ more calories than chow-fed controls $(p<0.0001)$. The greater calorie consumption resulted in the high fat-fed rats having $12 \%$ greater body weights than controls after 3 weeks $(p<0.05)$. Correspondingly, the hearts of the high fat-fed rats were $10 \%$ heavier than those from controls $(p<0.05)$, and in proportion to the increase in body weight, as all rats had the same heart/body weight ratios. High fat-fed rats had greater adiposity, as suggested by $67 \%$ larger epididymal fat pads $(p<0.01)$. In vivo ejection fractions, stroke volumes, heart rates and cardiac outputs were the same for all rats (Table 1).

Fasting blood plasma metabolites

All rats had similar fasting plasma levels of glucose and triglycerides (Table 1). Fasting plasma levels of free-fatty acids were elevated by $52 \%$ to $0.38 \mathrm{mM}$ in the high fat-fed rats when compared with $0.25 \mathrm{mM}$ in the control rats $(p<0.05)$. Total blood cholesterol levels were $25 \%$ higher in the high fat-fed rats at $2 \mathrm{mM}$ when compared with
Table 1 Daily dietary intake, morphological parameters, cardiac function and blood plasma metabolites from control (chow-fed) and high fat-fed rats

\begin{tabular}{|c|c|c|}
\hline & $\begin{array}{l}\text { Control } \\
(n=6)\end{array}$ & $\begin{array}{l}\text { High fat-fed } \\
(n=6)\end{array}$ \\
\hline \multicolumn{3}{|l|}{ Dietary intake } \\
\hline Food intake (g/day) & $17.5 \pm 1.7$ & $20 \pm 0.8$ \\
\hline Calorie intake (kcal/day) & $58 \pm 6$ & $102 \pm 4 * * * *$ \\
\hline \multicolumn{3}{|l|}{ Morphological data } \\
\hline Body weight (g) & $415 \pm 13$ & $466 \pm 17 *$ \\
\hline Heart weight (g) & $0.98 \pm 0.03$ & $1.08 \pm 0.03 *$ \\
\hline $\mathrm{HW} / \mathrm{BW} \times 1,000$ & $2.38 \pm 0.05$ & $2.34 \pm 0.06$ \\
\hline Epididymal fat weight (g) & $11.4 \pm 0.9$ & $19.0 \pm 1.8^{* *}$ \\
\hline \multicolumn{3}{|l|}{ In vivo cardiac MRI } \\
\hline Left ventricle mass $(\mathrm{g})$ & $0.45 \pm 0.03$ & $0.49 \pm 0.04$ \\
\hline Septal wall thickness $(\mathrm{mm})$ & $1.70 \pm 0.06$ & $1.75 \pm 0.1$ \\
\hline Ejection fraction $(\%)$ & $77 \pm 1$ & $74 \pm 1$ \\
\hline End-diastolic volume & $306 \pm 23$ & $307 \pm 20$ \\
\hline End-systolic volume & $70 \pm 6$ & $79 \pm 7$ \\
\hline Stroke volume $(\mu \mathrm{l})$ & $236 \pm 17$ & $228 \pm 16$ \\
\hline Heart rate (bpm) & $442 \pm 9$ & $473 \pm 27$ \\
\hline Cardiac output (ml.min $\left.{ }^{-1}\right)$ & $104 \pm 8$ & $108 \pm 10$ \\
\hline \multicolumn{3}{|l|}{ Fasting plasma metabolites } \\
\hline Glucose (mM) & $9.5 \pm 0.7$ & $11.2 \pm 1.1$ \\
\hline Triglycerides (mM) & $1.6 \pm 0.1$ & $1.9 \pm 0.2$ \\
\hline Free-fatty acids (mM) & $0.25 \pm 0.03$ & $0.38 \pm 0.04 *$ \\
\hline Total cholesterol (mM) & $1.6 \pm 0.1$ & $2.0 \pm 0.1^{*}$ \\
\hline LDL cholesterol (mM) & $0.04 \pm 0.01$ & $0.19 \pm 0.02 * * * *$ \\
\hline HDL cholesterol (mM) & $0.65 \pm 0.04$ & $0.88 \pm 0.11$ \\
\hline
\end{tabular}

$1.6 \mathrm{mM}$ in controls $(p<0.05)$, with an increased LDL cholesterol fraction of $0.19 \mathrm{mM}$ when compared with $0.04 \mathrm{mM}$ in controls $(p<0.0001)$, and no difference in the HDL cholesterol fraction.

\section{Isolated working heart}

Consistent with in vivo measurement of cardiac function, aortic flows were the same for all rat hearts at all palmitate concentrations (Fig. 2). Coronary flows were 15\% greater in high fat-fed rat hearts under all perfusion conditions $(p<0.04)$, but cardiac outputs were the same for all hearts. Therefore, high fat feeding had no significant effect on cardiac function, whether measured in vivo (Table 1) or in the isolated heart (Fig. 2).

Oxygen consumption in chow-fed rat hearts was significantly increased on perfusion with $1 \mathrm{mM}$ palmitate, when compared with perfusion with no palmitate, or with $0.2 \mathrm{mM}$ palmitate (Fig. 3, $p<0.02$ ). Overall, oxygen consumption in high fat-fed rat hearts was $19 \%$ higher than chow-fed rat 


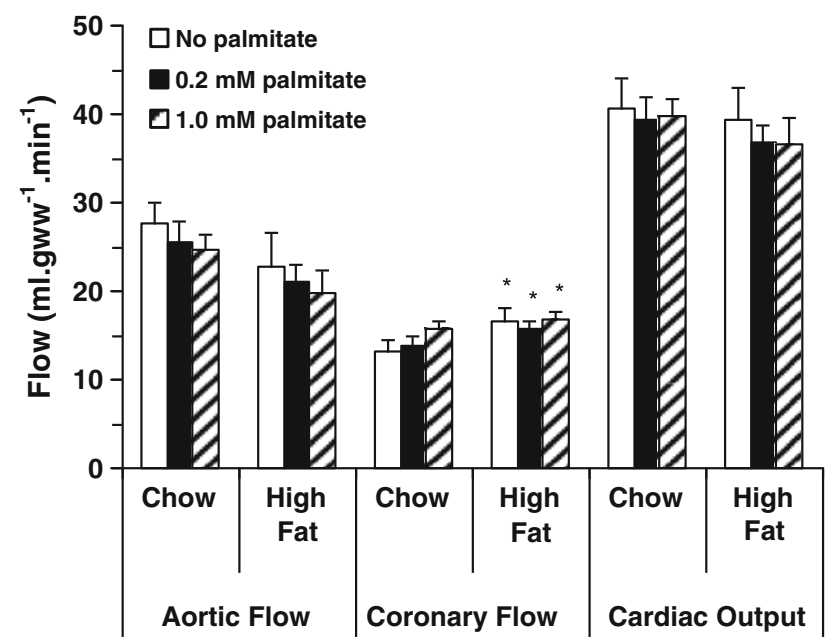

Fig. 2 Isolated working heart aortic flows, coronary flows and cardiac outputs (left to right) following 3 weeks of high fat feeding. Hearts were perfused with three buffers, all of which contained $11 \mathrm{mM}$ glucose, $0.2 \mathrm{mM}$ pyruvate and $0.5 \mathrm{mM}$ lactate as substrates (clear bars), and the addition of $0.2 \mathrm{mM}$ palmitate (shaded bars), or $1.0 \mathrm{mM}$ palmitate (hatched bars). $* p<0.05$ versus chow fed

hearts $(p<0.01)$, but was independent of palmitate concentration. Consistent with measurements of in vivo function, cardiac power in high fat-fed rat hearts $(8.8 \pm$ $0.7 \mathrm{~mW})$ was the same as chow-fed rat hearts $(9.4 \pm$ $0.6 \mathrm{~mW}$ ) under all perfusion conditions. Cardiac efficiency was higher in chow-fed rat hearts when perfused without palmitate than with either $0.2 \mathrm{mM}(p<0.01)$ or $1.0 \mathrm{mM}$ palmitate $(p<0.02)$. Cardiac efficiency was on average $21 \%$ lower in high fat-fed rat hearts than in chow-fed rat hearts (Fig. 3), as a consequence of the increased oxygen consumption. High fat-fed rat hearts had $43 \%$ lower efficiency as compared to chow-fed rat hearts when perfused without palmitate $(p<0.01)$, and $28 \%$ lower efficiency when perfused with $1.0 \mathrm{mM}$ palmitate $(p<0.05)$.
Respiration in isolated mitochondria

State 3 respiration rates were higher in isolated cardiac mitochondria from high fat-fed rats than chow-fed rats $(p<0.05)$ in the presence of palmitoyl carnitine and malate (Fig. 4), but were unchanged with pyruvate and malate or glutamate as substrates. The addition of the UCP3 inhibitor, GDP, did not significantly change state 3 respiration rates. With all substrates, state 4 respiration rates (Fig. 4) were not significantly different in cardiac mitochondria from high fat-fed when compared with chowfed animals, and were unchanged with the addition of GDP. ADP/O ratios were lower in cardiac mitochondria from high fat-fed rats as compared to those from chow-fed animals, irrespective of substrate $(p<0.01)$. The addition of GDP did not alter ADP/O ratios of mitochondria from chow-fed rat hearts (Fig. 4), but normalised the ADP/O ratio in high fat-fed rat heart mitochondria $(p<0.01)$ with all substrates.

MCAD and citrate synthase activity and GLUT 4 protein expression

Cardiac MCAD activity (Fig. 5) was 23\% higher in high fat-fed rat hearts $(p<0.05)$. Citrate synthase activity was the same for all hearts $\left(119 \pm 4 \mu \mathrm{mol} \mathrm{gww}^{-1} \mathrm{~min}^{-1}\right.$ after chow feeding and $124 \pm 6 \mu \mathrm{mol} \mathrm{gww}^{-1} \mathrm{~min}^{-1}$ after high fat feeding), indicating higher cardiac $\beta$-oxidation in high fat-fed animals with unchanged cardiac mitochondrial content. MCAD activity correlated positively $(p<0.001)$ with oxygen consumption in hearts perfused with $0.2 \mathrm{mM}$ palmitate (Fig. 5, $p<0.001$ ). Total cardiac protein levels of the insulin-sensitive glucose transporter, GLUT 4, were unchanged with high fat feeding $(1.0 \pm 0.06$ after chow feeding, $0.93 \pm 0.05$ after high fat feeding).

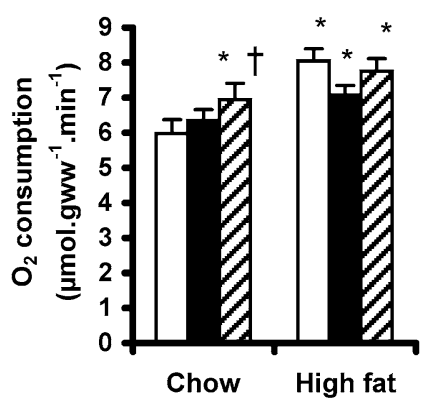

Fig. 3 Oxygen consumption (left), cardiac power (middle) and cardiac efficiency (right) in isolated rat hearts following high fat feeding. Hearts were perfused with three buffers, all of which contained $11 \mathrm{mM}$ glucose, $0.2 \mathrm{mM}$ pyruvate and $0.5 \mathrm{mM}$ lactate as

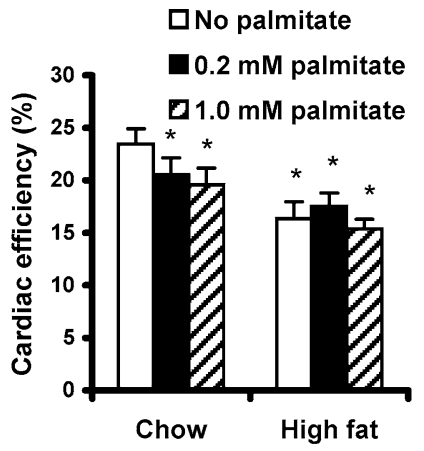

substrates (clear bars), and the addition of $0.2 \mathrm{mM}$ palmitate (shaded bars), or $1.0 \mathrm{mM}$ palmitate (hatched bars). $* p<0.05$ versus chowfed rat hearts perfused without palmitate, ${ }^{\dagger} p<0.05$ versus chow-fed rat hearts perfused with $0.2 \mathrm{mM}$ palmitate 

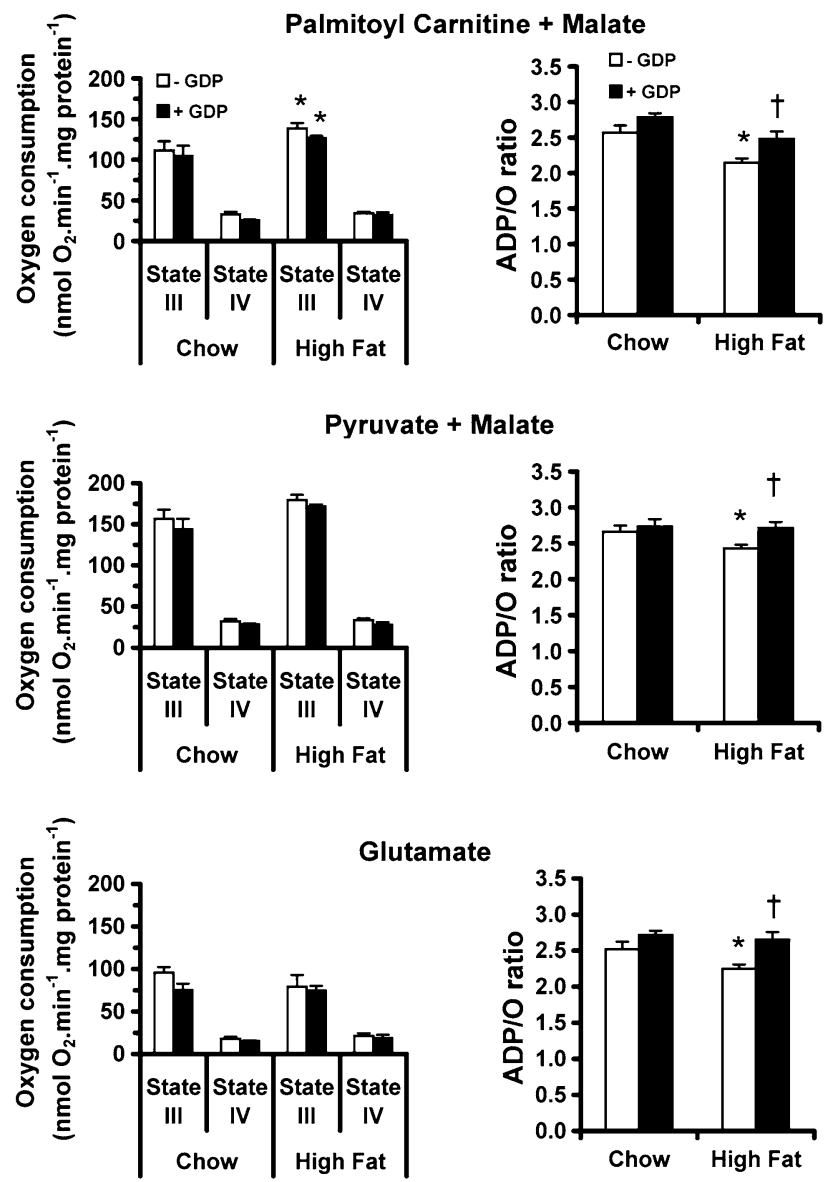

Fig. 4 State 3 respiration rates and $A D P / O$ ratios in rat left ventricular mitochondria with palmitoyl-carnitine plus malate (upper), pyruvate plus malate (middle) or glutamate (lower) as substrates. In addition to the control condition (clear bars), mitochondria were incubated with the UCP3 inhibitor GDP (shaded bars). $* p<0.05$ versus chow fed, ${ }^{\dagger} p<0.05$ versus high fat-fed without GDP

\section{Mitochondrial protein expression and modification}

UCP 3 and MTE-1 protein levels (Fig. 6) were both increased by $20 \%$ in high fat-fed rat hearts $(p<0.05)$.
Cardiac ANT and $\mathrm{F}_{0} \mathrm{~F}_{1}$ ATP synthase protein levels did not differ with high fat feeding (Fig. 6), supporting the finding that mitochondrial content had not changed with the high fat diet. Levels of protein carbonylation were the same in all cardiac mitochondria.

\section{Discussion}

In this study, we investigated cardiac function, efficiency and mitochondrial respiration in a rat model of dietinduced obesity in the absence of overt diabetes. A high fat diet increased body and epididymal fat pad weights, signifying greater body adiposity. Fasting plasma FFA levels were $52 \%$ higher in the high fat-fed animals, with increased total and LDL cholesterol. The high fat-fed rats were neither, however, hyperglycaemic in the fasting state, nor was cardiac GLUT 4 content decreased suggesting that cardiac glucose metabolism was normal in this short-term high fat feeding model. We found that isolated, perfused hearts from high fat-fed rats had decreased efficiency. The decreased cardiac efficiency following high fat feeding was solely due to increased oxygen consumption, and we suggest that this was caused by increased fatty acid oxidation and mitochondrial uncoupling.

\section{Cardiac insulin resistance}

We set out in this study to examine cardiac metabolism in a pre-diabetic model of early dietary-induced obesity, so there is a possibility that animals were insulin resistant after 3 weeks of high fat feeding. 4 weeks of feeding a $34 \%$ fat diet elevated plasma insulin [17], and 6-8 weeks of a $60 \%$ fat diet produced systemic glucose intolerance $[12,42]$. However, cardiac insulin sensitivity was normal after 8 weeks of feeding a $60 \%$ fat diet, a diet similar to that in the present study [12]. The heart appears to maintain a normal insulin response, despite systemic glucose intolerance, for a protracted period. For example, the obese
Fig. 5 Cardiac medium-chain acyl-CoA dehydrogenase (MCAD) activity (left) in chowfed (clear bars) and high fat-fed rats (shaded bars) $* p<0.05$ versus chow fed. Correlation between cardiac MCAD activity and oxygen consumption (right) in isolated perfused working heart from chow (open symbols) and high fat-fed rats (closed symbols)

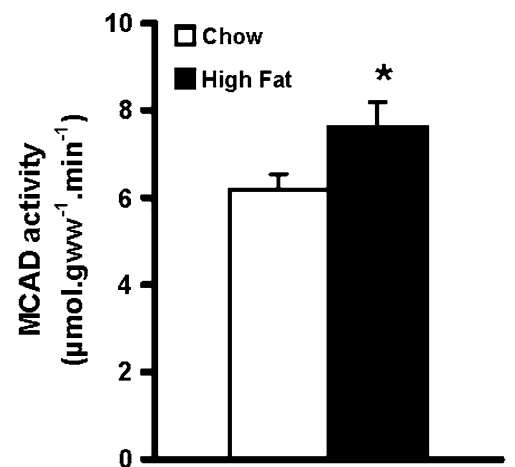




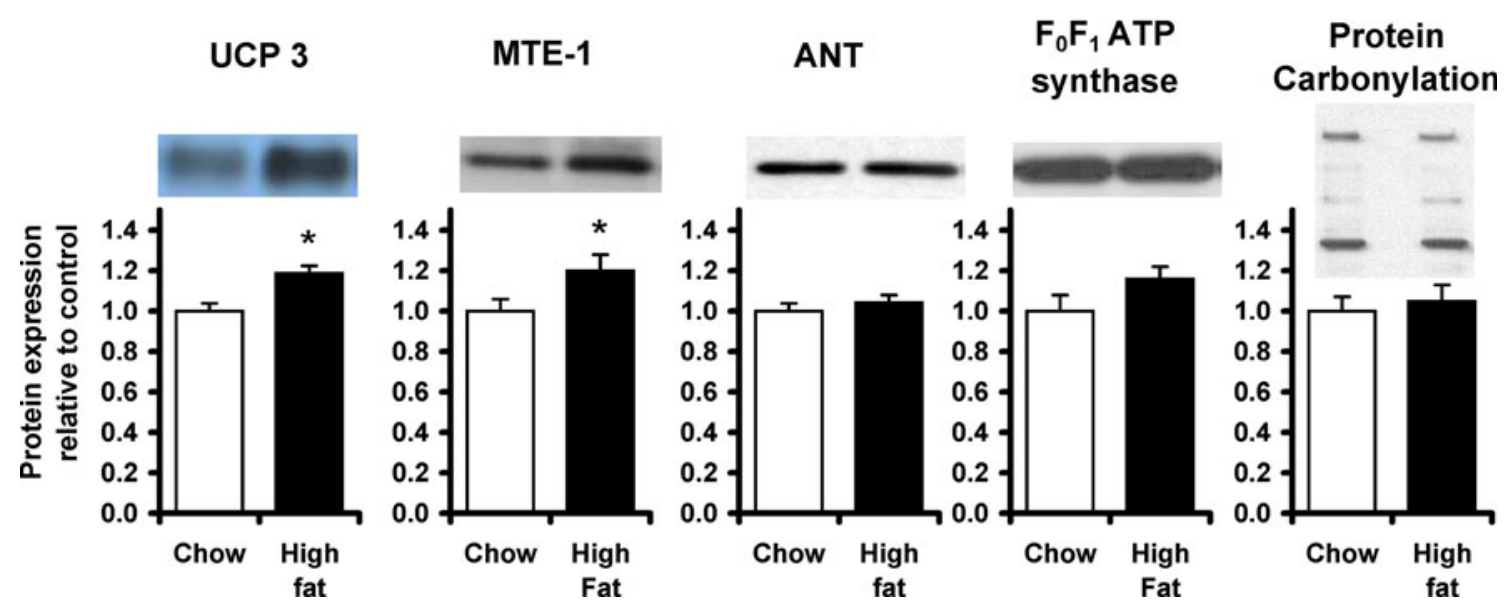

Fig. 6 Expression of mitochondrial inner membrane proteins, UCP3, MTE-1, ANT, $\mathrm{F}_{\mathrm{o}} \mathrm{F}_{1} \mathrm{ATP}$ synthase and protein carbonylation (left to right) in chow-fed (clear bars) and high fat-fed rats (shaded bars) $* p<0.05$ versus chow fed

Zucker rat had not developed cardiac insulin resistance by 6 months of age, and only had mild cardiac insulin resistance at 12 months [44]. Therefore, short-term high fat feeding has only a low likelihood of inducing cardiac insulin resistance.

\section{Cardiac function and efficiency}

Mechanical factors may have contributed to increased cardiac oxygen consumption in our rat hearts. Increased myocardial oxygen consumption has been closely linked to increased left ventricular wall stress [24, 46], however in vivo MRI measurements of cardiac function and morphology showed no abnormalities in end-diastolic volume or wall thickness in our high fat-fed rat hearts. In another study [43], high fat feeding increased systolic blood pressure by $\sim 40 \%$, which would increase wall stress, but afterload and hydraulic resistance were constant in our isolated working heart preparation, so the effects of blood pressure were not relevant. These results indicated to us that the increase in oxygen consumption was due to changes in cardiac metabolism, rather than mechanical factors. High fat-fed rats had normal cardiac function when measured in vivo or when hearts were perfused in working mode, and thus it seems that ATP synthesis was maintained. However, oxygen consumption was increased, with the result that cardiac efficiency was decreased in high fat-fed rat hearts.

\section{Fatty acid oxidation}

We found that high fat-fed rat hearts had increased mitochondrial fatty acid oxidation when compared with control rat hearts. Mitochondria from high fat-fed rat hearts had increased state 3 respiration only in the presence of palmitoyl-carnitine, whereas respiration was normal with pyruvate or glutamate. It is likely, therefore, that the increased respiration rate was associated with the upregulation of enzymes of fat metabolism, such as MCAD (Fig. 1), which increases in heart following PPAR $\alpha$ activation [19]. MCAD activity was elevated by $23 \%$ in high fat-fed rat hearts, similar to the increase in mitochondrial fatty acid oxidation, but citrate synthase activity and protein levels of $\mathrm{F}_{0} \mathrm{~F}_{1}$ ATP synthase and ANT were unaltered, therefore an increase in the number of mitochondria could not account for these differences.

Our finding of increased fatty acid oxidation and MCAD activity is consistent with long-term high fat feeding studies [32, 37]. Increased fatty acid oxidation has been reported in isolated, perfused working rat hearts after 4 weeks of feeding a $60 \%$ saturated fat diet, but this was not associated with decreased cardiac efficiency [51]. Fatty acid oxidation is unaltered in rats bred for low aerobic capacity with moderate obesity [41]. In the present study, a switch in substrate preference away from more oxygen efficient glucose oxidation, towards fatty acid oxidation with high fat feeding [5] may have contributed to an increase in oxygen consumption and decrease in cardiac efficiency. This effect would be relatively minor, as the maximum difference in oxygen consumption between glucose oxidation alone to palmitate oxidation alone is 10-12\% [5, 49]. Therefore, increased fatty acid oxidation would have played a minor role in decreasing cardiac efficiency with high fat feeding.

High FFAs increased oxygen consumption by up to $40 \%$ in either unloaded or arrested isolated hearts on perfusion with $>1 \mathrm{mM}$ fatty acids $[2,11]$, and in vivo infusion of $10 \%$ intra-lipid increased oxygen consumption by $26 \%$ [28]. In our study, there was a $20 \%$ increase in oxygen consumption on perfusion with $1 \mathrm{mM}$ fatty acids, and in proportion to the exogenous fatty acid supply (Fig. 3). The mechanisms 
responsible for such increases in oxygen consumption in the normal heart remain unclear, but may be related to direct action of FFAs on mitochondrial uncoupling [36]. We found that mitochondrial $\mathrm{ADP} / \mathrm{O}$ ratios from chow-fed rat hearts were not affected by GDP, indicating that uncoupling proteins were not responsible for the increased oxygen consumption in hearts from chow-fed animals. However, this does not discount the possibility that direct action of FFAs cause uncoupling [36] in the absence of changes in mitochondrial proteins. In contrast to chow-fed rat hearts, high fat-fed rat hearts had significantly elevated oxygen consumption even when no exogenous FFA was present, with reduced cardiac efficiency, which cannot be explained by the mechanisms described above [2, 36, 38]. This, therefore, points to abnormalities in oxidative metabolism downstream of substrate supply (Fig. 1).

\section{Mitochondrial respiration and UCP protein expression}

The finding that oxygen consumption in the high fat-fed isolated heart was increased may be explained by differences in mitochondrial metabolism. Evidence from both mitochondrial respiration and protein expression indicate that mitochondria of high fat-fed hearts were more uncoupled than chow-fed hearts. In earlier work, we found that decreased efficiency in the hyperthyroid or chronically infarcted rat heart was associated with increased mitochondrial UCP3 protein levels and increased uncoupling $[3,30]$. In high fat-fed rats, increased UCP3 levels were associated with decreased phosphorylation/oxidation coupling of interfibrillar mitochondria with all substrates tested (Fig. 1), which may explain why cardiac oxygen consumption in high fat-fed isolated hearts was increased irrespective of perfusion substrate. In isolated high fat-fed rat cardiac mitochondria, inhibition of UCP3 increased phosphorylation efficiency to control levels. Cardiac levels of UCP3 are elevated in severe rodent models of type 2 diabetes [31], type 1 diabetes [31], hyperthyroidism [3] and heart failure [30], all of which are characterised by elevated plasma FFA levels. However, increased cardiac UCP3 levels in disease models have not always been found [4, 9, 10], despite increased proton leak in isolated cardiac mitochondria [4, 22]. Here, we found that diet-induced elevation of plasma FFAs was sufficient to elevate cardiac levels of both UCP3 and MTE-1 by $20 \%$. UCP3 and MTE1 are upregulated in heart via activation of $\operatorname{PPAR} \alpha[18,45]$, and it has been suggested that the two proteins might act in concert to export fatty acid anions from the mitochondrial matrix as a protective mechanism [21] or to increase fatty acid oxidation [45]. High fat feeding did not, however, alter cardiac levels of ANT, another putative mitochondrial uncoupler of rat heart mitochondria [7, 40], or the $\alpha$-subunit of the $\mathrm{F}_{0} \mathrm{~F}_{1}$ ATP synthase. Therefore, mitochondrial uncoupling, not increased numbers of mitochondria, may explain the increased oxygen consumption and decreased efficiency of the high fat-fed rat heart.

A positive consequence of an increase in UCP3 protein and uncoupling of mitochondrial respiration may be that cardiac ROS production from the electron transport chain is reduced $[6,14]$ as the electrochemical gradient driving the electron transport chain becomes dissipated. Several studies report reduced ROS production with an increase in UCP3 protein [13, 47], a relationship supported by the reverse observation, in that decreased cardiac UCP3 protein is accompanied by increased ROS production [8]. We found no evidence of mitochondrial oxidative protein modification with high fat feeding, indicating that ROSmediated damage was unaltered. More prolonged high fat feeding may be required to produce oxidative protein modification; others have shown that although total myocardial protein carbonylation was unaltered after 4 weeks, it had increased after 16 weeks of feeding a $60 \%$ fat diet [51]. Thus, the duration of high fat feeding was probably insufficient for the increased UCP3 proteins to have a measureable effect on ROS generation and oxidative protein modification.

\section{Conclusion}

In conclusion, we have demonstrated that high fat dietinduced obesity, in the absence of overt diabetes, increased mitochondrial UCP3 levels and the capacity for fatty acid oxidation in cardiac mitochondria, resulting in mitochondrial uncoupling. In the absence of changes in cardiac function, oxygen consumption increased, thereby decreasing cardiac efficiency. Thus, mitochondrial uncoupling may underlie the cardiac energetic abnormalities observed in diabetic patients prior to the development of functional impairment [39].

Acknowledgments We thank Emma Carter for her invaluable technical assistance, and Dr Charles L Hoppel and his research group for their generous help in teaching us their mitochondrial isolation and respiration protocols. Stefan Alexson is thanked for his generous gift of the MTE-1 antibody. Sara McAleese thanks the Wellcome Trust for her Undergraduate Vacation Studentship. This study was supported by the British Heart Foundation, grant number RG/02/009/ 13631.

Conflict of interest The authors declare that they have no conflict of interest.

Open Access This article is distributed under the terms of the Creative Commons Attribution Noncommercial License which permits any noncommercial use, distribution, and reproduction in any medium, provided the original author(s) and source are credited. 


\section{References}

1. Alberti KG, Zimmet P, Shaw J (2005) The metabolic syndromea new worldwide definition. Lancet 366:1059-1062. doi:10.1016/ S0140-6736(05)67402-8

2. Boardman N, Hafstad AD, Larsen TS, Severson DL, Aasum E (2009) Increased $\mathrm{O}_{2}$ cost of basal metabolism and excitationcontraction coupling in hearts from type 2 diabetic mice. Am J Physiol Heart Circ Physiol 296:H1373-H1379. doi:10.1152/ ajpheart.01264.2008

3. Boehm EA, Jones BE, Radda GK, Veech RL, Clarke K (2001) Increased uncoupling proteins and decreased efficiency in palmitate-perfused hyperthyroid rat heart. Am J Physiol Heart Circ Physiol 280:H977-H983

4. Boudina S, Sena S, Theobald H, Sheng X, Wright JJ, Hu XX, Aziz S, Johnson JI, Bugger H, Zaha VG, Abel ED (2007) Mitochondrial energetics in the heart in obesity-related diabetes: direct evidence for increased uncoupled respiration and activation of uncoupling proteins. Diabetes 56:2457-2466. doi:10.2337/ $\mathrm{db} 07-0481$

5. Brand MD (2005) The efficiency and plasticity of mitochondrial energy transduction. Biochem Soc Trans 33:897-904. doi: 10.1042/BST20050897

6. Brand MD, Affourtit C, Esteves TC, Green K, Lambert AJ, Miwa S, Pakay JL, Parker N (2004) Mitochondrial superoxide: production, biological effects, and activation of uncoupling proteins. Free Radic Biol Med 37:755-767. doi:10.1016/j.freeradbiomed. 2004.05.034

7. Brand MD, Pakay JL, Ocloo A, Kokoszka J, Wallace DC, Brookes PS, Cornwall EJ (2005) The basal proton conductance of mitochondria depends on adenine nucleotide translocase content. Biochem J 392:353-362. doi:10.1042/BJ20050890

8. Bugger H, Guzman C, Zechner C, Palmeri M, Russell KS, Russell RR, 3rd (2010) Uncoupling protein downregulation in doxorubicin-induced heart failure improves mitochondrial coupling but increases reactive oxygen species generation. Cancer Chemother Pharmacol. doi:10.1007/s00280-010-1441-7

9. Carley AN, Atkinson LL, Bonen A, Harper ME, Kunnathu S, Lopaschuk GD, Severson DL (2007) Mechanisms responsible for enhanced fatty acid utilization by perfused hearts from type 2 diabetic db/db mice. Arch Physiol Biochem 113:65-75. doi: $10.1080 / 13813450701422617$

10. Carley AN, Severson DL (2005) Fatty acid metabolism is enhanced in type 2 diabetic hearts. Biochim Biophys Acta 1734:112-126. doi:10.1016/j.bbalip.2005.03.005

11. Challoner DR, Steinberg D (1966) Effect of free fatty acid on the oxygen consumption of perfused rat heart. Am J Physiol 210:280-286

12. Christopher BA, Huang HM, Berthiaume JM, McElfresh TA, Chen X, Croniger CM, Muzic RF Jr, Chandler MP (2010) Myocardial insulin resistance induced by high fat feeding in heart failure is associated with preserved contractile function. Am J Physiol Heart Circ Physiol 299:H1917-H1927. doi:10.1152/ ajpheart.00687.2010

13. Costford SR, Seifert EL, Bezaire V, FG M, Bevilacqua L, Gowing A, Harper ME (2007) The energetic implications of uncoupling protein-3 in skeletal muscle. Appl Physiol Nutr Metab 32:884-894. doi:10.1139/h07-063

14. Di Lisa F, Kaludercic N, Carpi A, Menabo R, Giorgio M (2009) Mitochondrial pathways for ROS formation and myocardial injury: the relevance of p66(Shc) and monoamine oxidase. Basic Res Cardiol 104:131-139. doi:10.1007/s00395-009-0008-4

15. Eckel RH, Grundy SM, Zimmet PZ (2005) The metabolic syndrome. Lancet 365:1415-1428. doi:10.1016/S0140-6736(05) 66378-7
16. Estabrook RW (1967) Mitochondrial respiratory control and the polarographic measurement of ADP:O ratios. In: Estabrook RW, Pullman ME (eds) Methods in enzymology. Academic Press, pp 41-47

17. Ghaboura N, Tamareille S, Ducluzeau PH, Grimaud L, Loufrani L, Croue A, Tourmen Y, Henrion D, Furber A, Prunier F (2010) Diabetes mellitus abrogates erythropoietin-induced cardioprotection against ischemic-reperfusion injury by alteration of the RISK/GSK-3beta signaling. Basic Res Cardiol. doi:10.1007/ s00395-010-0130-3

18. Gilde AJ, Van Bilsen M (2003) Peroxisome proliferator-activated receptors (PPARS): regulators of gene expression in heart and skeletal muscle. Acta Physiol Scand 178:425-434

19. Gilde AJ, van der Lee KA, Willemsen PH, Chinetti G, van der Leij FR, van der Vusse GJ, Staels B, van Bilsen M (2003) Peroxisome proliferator-activated receptor (PPAR) alpha and PPARbeta/delta, but not PPARgamma, modulate the expression of genes involved in cardiac lipid metabolism. Circ Res 92:518-524. doi:10.1161/01.RES.0000060700.55247.7C

20. Heather LC, Cole MA, Lygate CA, Evans RD, Stuckey DJ, Murray AJ, Neubauer S, Clarke K (2006) Fatty acid transporter levels and palmitate oxidation rate correlate with ejection fraction in the infarcted rat heart. Cardiovasc Res 72:430-437. doi: 10.1016/j.cardiores.2006.08.020

21. Himms-Hagen J, Harper ME (2001) Physiological role of UCP3 may be export of fatty acids from mitochondria when fatty acid oxidation predominates: an hypothesis. Exp Biol Med (Maywood) $226: 78-84$

22. How OJ, Aasum E, Severson DL, Chan WY, Essop MF, Larsen TS (2006) Increased myocardial oxygen consumption reduces cardiac efficiency in diabetic mice. Diabetes 55:466-473

23. How OJ, Larsen TS, Hafstad AD, Khalid A, Myhre ES, Murray AJ, Boardman NT, Cole M, Clarke K, Severson DL, Aasum E (2007) Rosiglitazone treatment improves cardiac efficiency in hearts from diabetic mice. Arch Physiol Biochem 113:211-220. doi:10.1080/13813450701783281

24. Jones JV, Serafi AS, James MA (2000) Wall stress and the heart. J Cardiovasc Risk 7:159-161

25. Kerner J, Turkaly PJ, Minkler PE, Hoppel CL (2001) Aging skeletal muscle mitochondria in the rat: decreased uncoupling protein-3 content. Am J Physiol Endocrinol Metab 281:E1054E1062

26. King KL, Young ME, Kerner J, Huang H, O'Shea KM, Alexson SE, Hoppel CL, Stanley WC (2007) Diabetes or peroxisome proliferator-activated receptor alpha agonist increases mitochondrial thioesterase I activity in heart. J Lipid Res 48:1511-1517. doi:10.1194/jlr.M600364-JLR200

27. Maffei M, Fei H, Lee GH, Dani C, Leroy P, Zhang Y, Proenca R, Negrel R, Ailhaud G, Friedman JM (1995) Increased expression in adipocytes of ob RNA in mice with lesions of the hypothalamus and with mutations at the db locus. Proc Natl Acad Sci USA 92:6957-6960

28. Mjos OD (1971) Effect of free fatty acids on myocardial function and oxygen consumption in intact dogs. J Clin Invest 50:13861389. doi: $10.1172 / \mathrm{JCI} 106621$

29. Murray AJ, Anderson RE, Watson GC, Radda GK, Clarke K (2004) Uncoupling proteins in human heart. Lancet 364:17861788. doi:10.1016/S0140-6736(04)17402-3

30. Murray AJ, Cole MA, Lygate CA, Carr CA, Stuckey DJ, Little SE, Neubauer S, Clarke K (2008) Increased mitochondrial uncoupling proteins, respiratory uncoupling and decreased efficiency in the chronically infarcted rat heart. J Mol Cell Cardiol 44:694-700. doi:10.1016/j.yjmcc.2008.01.008

31. Murray AJ, Panagia M, Hauton D, Gibbons GF, Clarke K (2005) Plasma free fatty acids and peroxisome proliferator-activated 
receptor alpha in the control of myocardial uncoupling protein levels. Diabetes 54:3496-3502

32. Okere IC, Chandler MP, McElfresh TA, Rennison JH, Kung TA, Hoit BD, Ernsberger P, Young ME, Stanley WC (2007) Carnitine palmitoyl transferase-I inhibition is not associated with cardiac hypertrophy in rats fed a high-fat diet. Clin Exp Pharmacol Physiol 34:113-119. doi:10.1111/j.1440-1681.2007.04545.x

33. Palmer JW, Tandler B, Hoppel CL (1977) Biochemical properties of subsarcolemmal and interfibrillar mitochondria isolated from rat cardiac muscle. J Biol Chem 252:8731-8739

34. Panagia M, Gibbons GF, Radda GK, Clarke K (2005) PPARalpha activation required for decreased glucose uptake and increased susceptibility to injury during ischemia. Am J Physiol Heart Circ Physiol 288:H2677-H2683. doi:10.1152/ajpheart. 00200.2004

35. Pelleymounter MA, Cullen MJ, Baker MB, Hecht R, Winters D, Boone T, Collins F (1995) Effects of the obese gene product on body weight regulation in ob/ob mice. Science 269:540-543

36. Ray J, Noll F, Daut J, Hanley PJ (2002) Long-chain fatty acids increase basal metabolism and depolarize mitochondria in cardiac muscle cells. Am J Physiol Heart Circ Physiol 282:H1495H1501. doi:10.1152/ajpheart.00696.2001

37. Rennison JH, McElfresh TA, Chen X, Anand VR, Hoit BD, Hoppel CL, Chandler MP (2009) Prolonged exposure to high dietary lipids is not associated with lipotoxicity in heart failure. J Mol Cell Cardiol 46:883-890. doi:10.1016/j.yjmcc.2009.02.019

38. Reszko AE, Kasumov T, David F, Jobbins KA, Thomas KR, Hoppel CL, Brunengraber H, Des Rosiers C (2004) Peroxisomal fatty acid oxidation is a substantial source of the acetyl moiety of malonyl-CoA in rat heart. J Biol Chem 279:19574-19579. doi: 10.1074/jbc.M400162200

39. Scheuermann-Freestone M, Madsen PL, Manners D, Blamire AM, Buckingham RE, Styles P, Radda GK, Neubauer S, Clarke $\mathrm{K}$ (2003) Abnormal cardiac and skeletal muscle energy metabolism in patients with type 2 diabetes. Circulation 107:30403046. doi:10.1161/01.CIR.0000072789.89096.10

40. Schonfeld P (1990) Does the function of adenine nucleotide translocase in fatty acid uncoupling depend on the type of mitochondria? FEBS Lett 264:246-248

41. Schwarzer M, Britton SL, Koch LG, Wisloff U, Doenst T (2010) Low intrinsic aerobic exercise capacity and systemic insulin resistance are not associated with changes in myocardial substrate oxidation or insulin sensitivity. Basic Res Cardiol 105:357-364. doi:10.1007/s00395-010-0087-2

42. Setty S, Sun W, Tune JD (2003) Coronary blood flow regulation in the prediabetic metabolic syndrome. Basic Res Cardiol 98:416-423. doi:10.1007/s00395-003-0418-7

43. Sharma N, Okere IC, Duda MK, Johnson J, Yuan CL, Chandler MP, Ernsberger P, Hoit BD, Stanley WC (2007) High fructose diet increases mortality in hypertensive rats compared to a complex carbohydrate or high fat diet. Am J Hypertens 20:403-409. doi:10.1016/j.amjhyper.2006.09.022

44. Sidell RJ, Cole MA, Draper NJ, Desrois M, Buckingham RE, Clarke K (2002) Thiazolidinedione treatment normalizes insulin resistance and ischemic injury in the zucker Fatty rat heart. Diabetes 51:1110-1117

45. Stavinoha MA, RaySpellicy JW, Essop MF, Graveleau C, Abel ED, Hart-Sailors ML, Mersmann HJ, Bray MS, Young ME (2004) Evidence for mitochondrial thioesterase 1 as a peroxisome proliferator-activated receptor-alpha-regulated gene in cardiac and skeletal muscle. Am J Physiol Endocrinol Metab 287:E888E895. doi:10.1152/ajpendo.00190.2004

46. Strauer BE (1979) Myocardial oxygen consumption in chronic heart disease: role of wall stress, hypertrophy and coronary reserve. Am J Cardiol 44:730-740

47. Toime LJ, Brand MD (2010) Uncoupling protein-3 lowers reactive oxygen species production in isolated mitochondria. Free Radic Biol Med 49:606-611. doi:10.1016/j.freeradbiomed.2010. 05.010

48. Tyler DJ, Lygate CA, Schneider JE, Cassidy PJ, Neubauer S, Clarke K (2006) CINE-MR imaging of the normal and infarcted rat heart using an $11.7 \mathrm{~T}$ vertical bore MR system. J Cardiovasc Magn Reson 8:327-333

49. Ussher JR, Lopaschuk GD (2009) Targeting malonyl CoA inhibition of mitochondrial fatty acid uptake as an approach to treat cardiac ischemia/reperfusion. Basic Res Cardiol 104:203-210. doi:10.1007/s00395-009-0003-9

50. Vettor R, Fabris R, Serra R, Lombardi AM, Tonello C, Granzotto M, Marzolo MO, Carruba MO, Ricquier D, Federspil G, Nisoli E (2002) Changes in FAT/CD36, UCP2, UCP3 and GLUT4 gene expression during lipid infusion in rat skeletal and heart muscle. Int J Obes Relat Metab Disord 26:838-847. doi:10.1038/sj.ijo. 0802005

51. Wilson CR, Tran MK, Salazar KL, Young ME, Taegtmeyer H (2007) Western diet, but not high fat diet, causes derangements of fatty acid metabolism and contractile dysfunction in the heart of Wistar rats. Biochem J 406:457-467. doi:10.1042/BJ20070392

52. Woo MN, Bok SH, Lee MK, Kim HJ, Jeon SM, Do GM, Shin SK, Ha TY, Choi MS (2008) Anti-obesity and hypolipidemic effects of a proprietary herb and fiber combination (S\&S PWH) in rats fed high-fat diets. J Med Food 11:169-178. doi:10.1089/jmf. 2007.082

53. Zackova M, Skobisova E, Urbankova E, Jezek P (2003) Activating omega- 6 polyunsaturated fatty acids and inhibitory purine nucleotides are high affinity ligands for novel mitochondrial uncoupling proteins UCP2 and UCP3. J Biol Chem 278:2076120769. doi:10.1074/jbc.M212850200 